\title{
Comparison of five viral nucleic acid extraction kits for the efficient extraction of viral DNA and RNA from cell-free samples
}

\author{
Bandar Ali Suliman* \\ Department of Medical Laboratory Technology, College of Applied Medical Sciences, Taibah University, Madinah, Saudi Arabia
}

\begin{abstract}
Extraction of viral nucleic acids from serum samples is widely used in diagnostic pathology tests. However, the heterogeneous nature of non-serum samples may contribute to variations in the yields of viral nucleic acids with different extraction methods and specimen types. Five different nucleic acid extraction methods were compared for optimal extraction of viral DNA or RNA from a prepared cell-free specimen. The viruses used were hepatitis B, hepatitis C. The specimen used was DNase and RNase free normal saline spiked with predefined quantities of viral DNA or RNA. The extraction protocol was carried out according to each manufacturer's recommendations. The extracted nucleic acids from each of the samples were amplified by PCR and compared to the original un-extracted standard control. The RTA kit as well as the Qiagen kit was shown to yield the highest amounts of viral nucleic acid.
\end{abstract}

\section{Introduction}

The ability to extract high purity viral nucleic acid, either DNA or RNA, is required for many downstream molecular and medical techniques used in research or diagnostic purposes. The efficient extraction of viral nucleic acid is imperative in delivering intact, undamaged and contamination-free starting materials for the very sensitive method of polymerase chain reaction (PCR) [1,2].

The amplification of viral nucleic acid; either DNA using qualitative real-time PCR (qPCR), or RNA using qualitative revers-transcription real-time PCR (qRT-PCR), is widely used in the field of molecular diagnostics [3]. The procedure determines the copy number, commonly known as the "viral load", in the blood of patients infected with certain virtues, such as hepatitis $B$, hepatitis $C$, human immunodeficiency virus (HIV), and many other viral infections [4-6].

Although many manufacturers of real-time thermal cyclers claim that their instruments are able to detect a single nucleic acid target in samples with a slow as few copy numbers [7]; their claim is usually affected by various factors and conditions. One of the most important factors affecting the instrument's ability to detect its nucleic acid target is the integrity of the extracted viral nucleic acid [8].

Many commercially available viral nucleic acid extraction kits use the silica-based column extraction methodology. This method relies on the ability of silica particles to adsorb DNA and RNA molecules under certain analytical conditions, including the presence of ethanol, salt concentration and $\mathrm{pH}$ [9]. Newer technologies depend on silica-coated magnetic nanoparticles that delivers the same binding capacity, but more developed to use in automated extraction devices [10]. The nucleic acid is then precipitated and ultimately eluted using special buffers or simply nuclease-free water. Each manufacturer, however, modifies their kit components to alter the binding and subsequent release of viral nucleic acid. This creates considerable variability in terms of binding capacity, contaminant removal and overall extraction efficacy [11].
Additionally, viral RNA extraction is different from viral DNA extraction. Not only the physical and biochemical properties and $3 \mathrm{D}$ structure of RNA and DNA are different, but also, how these molecules aggregate to form a precipitate that can be successfully eluted. Many modern commercial kits use poly-A carrier RNA molecules to facilitate the aggregation of viral, which is usually present in minute quantities in patients' samples [12].

In this project, we compared the yield and purity of viral nucleic acid using five different commercially extraction kits and determined their extraction efficiency using PCR amplification followed by Ct value comparison.

\section{Methods}

\section{Viral samples}

Two different solutions were used to prepare the samples from which the viral nucleic acid was extracted. The first solution was normal saline and the second solution was pooled serum extracted from blood samples of healthy donor individuals. $3 \mu \mathrm{L}$ of $2 \times 105 \mathrm{HBV}$ positive control template from the PCRmax Hepatitis B Virus kit (Cat\# PKIT10047, PCRmax, Staffordshire, United Kingdom) as well as $3 \mu \mathrm{L}$ of $2 \times 105 \mathrm{HCV}$ positive control template from the PCRmax Hepatitis C Virus kit (Cat\# PKIT10051, PCRmax, Staffordshire, United Kingdom) were added to $1.5 \mathrm{~mL}$ of both solutions. Both un-extracted solutions are

${ }^{\star}$ Correspondence to: Bandar Ali Suliman, Department of Medical Laboratory Technology, College of Applied Medical Sciences, Taibah University, Madinah, Saudi Arabia, E-mail: bsuliman@taibahu.edu.sa

Key words: viral DNA, viral RNA, molecular immunology, viral load, $q P C R, q R T$ $P C$

Received: July 17, 2019; Accepted: August 13, 2019; Published: August 16, 2019 
then used as controls for viral nucleic acid concentrations as well as in real-time PCR experiments.

\section{Viral nucleic acid extraction}

We used five different commercially available viral nucleic acid extraction kits. RTA Viral Nucleic Acid Isolation Kit (Cat\# 09029100, RTA Laboratories, Gebze, Turkey). Magnetic Beads Viral DNA/RNA Extraction Kit (Cat\# MV096, Geneaid, New Taipei City, Taiwan). AccuPrep Viral RNA Extraction Kit (Cat\# K-3033R, Bioneer, Daedeokgu, Republic of Korea). QIAamp DSP Virus Kit (Cat\# 60704, Qiagen, Hilden, Germany). HigherPurity Viral DNA/RNA Kit (Cat\# AN0605, Canvax, Córdoba, Spain). In this project, the kits were named: R, G, B, $\mathrm{Q}$ and $\mathrm{C}$ respectively.

For the R kit; $20 \mu \mathrm{L}$ of Proteinase $\mathrm{K}$ was added to $250 \mu \mathrm{L}$ of both solutions into a $2 \mathrm{ml}$ tube. Then, $750 \mu \mathrm{L}$ of Solution RL and $15 \mu \mathrm{L}$ of RNA Carrier was added to each tube followed by quick mixing using pulsevortex. Both tubes were incubated at $56^{\circ} \mathrm{C}$ and then briefly centrifuged at $1,500 \mathrm{~g}$ for 1 minute. Next $750 \mu \mathrm{L}$ of $97 \%$ ethanol was added, mixed by pulse-vortex and incubated again at room temperature for 3 minutes. After that, $900 \mu \mathrm{L}$ of the mixture was transferred to the spin column and centrifuge at 5,000 $\mathrm{g}$ for 1 minute discarding the flow-through; this step was repeated twice. Then $700 \mu \mathrm{L}$ of solution $\mathrm{W} 1$ was added before centrifuging the tubes at 5,000 $\mathrm{g}$ for 1 minute, and the same process was repeated using solution W2. After a final step of washing using $700 \mu \mathrm{L}$ of $97 \%$ ethanol, both tubes were centrifuged at $16,000 \mathrm{~g}$ for 1 minute and the tubes caps were left open to dry any residual ethanol at $60^{\circ} \mathrm{C}$ for 10 minutes. Viral nucleic acid was eventually eluted by adding $50 \mu \mathrm{L}$ of solution $\mathrm{E}$ and centrifuging the tubes at $16,000 \mathrm{~g}$ for 3 minutes.

For the G kit; $400 \mu \mathrm{L}$ of MV1 buffer and $10 \mu \mathrm{L}$ of RNA Carrier were added to $200 \mu \mathrm{L}$ of both solutions into a $2 \mathrm{ml}$ tube followed by quick mixing using pulse-vortex and incubation at room temperature for 10 minutes. Then, $450 \mu \mathrm{L}$ of MV2 buffer and $50 \mu \mathrm{L}$ of well-mixed MV magnetic beads was added to each tube, mixed by pulse-vortex and the all the supernatant was removed using a magnetic separator. Washing was performed by adding $400 \mu \mathrm{L}$ of MV3 buffer and two rounds of 600 $\mu \mathrm{L}$ of MV4 buffer followed by heating the tubes at $40^{\circ} \mathrm{C}$ for 3 minutes to dry the magnetic beads. Viral nucleic acid was eventually eluted by adding $50 \mu \mathrm{L}$ of nuclease free water and removing it using the magnetic separator.

For the B kit; $10 \mu \mathrm{L}$ of Proteinase $\mathrm{K}$ was added to $200 \mu \mathrm{L}$ of both solutions into a $2 \mathrm{ml}$ tube. Then, $300 \mu \mathrm{L}$ of $\mathrm{VB}$ buffer was added to each tube followed by quick mixing using pulse-vortex. Both tubes were incubated at $56^{\circ} \mathrm{C}$ for 10 minutes. Next $300 \mu \mathrm{L}$ of $99 \%$ isopropanol was added, mixed by pulse-vortex and the centrifuged at 8,000 rpm for 1 minute to discard the flow-through. After that, $500 \mu \mathrm{L}$ of VW1 buffer was added before centrifuging the tubes at $8,000 \mathrm{rpm}$ for 1 minute, and the same process was repeated using RWA2 buffer. Viral nucleic acid was eventually eluted by adding $50 \mu \mathrm{L}$ of ER buffer and centrifuging the tubes at $8,000 \mathrm{rpm}$ for 1 minute.

For the Q kit; $75 \mu \mathrm{L}$ of QP buffer, $500 \mu \mathrm{L}$ of the AL buffer and 11.2 $\mu \mathrm{g} / \mathrm{mL}$ of RNA Carrier were added to $500 \mu \mathrm{L}$ of each solution into a 2 $\mathrm{ml}$ tube. Both tubes were incubated at $56^{\circ} \mathrm{C}$ and for 15 minutes then centrifuged at 13,000 g for 1 minutes. Next, $600 \mu \mathrm{L}$ of $97 \%$ ethanol was added, mixed by pulse-vortex, incubated at room temperature for 5 minutes and centrifuged at $13,000 \mathrm{~g}$ for 1 minute. Then $600 \mu \mathrm{L}$ of AW 1 was added before centrifuging the tubes at 13,000 g for 1 minute, and the same process was repeated using $\mu \mathrm{L} 750$ of AW2. After a final step of washing using $750 \mu \mathrm{L}$ of $97 \%$ ethanol, both tubes were centrifuged at $16,000 \mathrm{~g}$ for 1 minute and the tubes caps were left open to dry any residual ethanol at $56^{\circ} \mathrm{C}$ for 3 minutes. Viral nucleic acid was eventually eluted by adding $50 \mu \mathrm{L}$ of AVE buffer and centrifuging the tubes at $16,000 \mathrm{~g}$ for 3 minutes.

For the $\mathrm{C}$ kit; $25 \mu \mathrm{L}$ of proteinase $\mathrm{K}, 200 \mu \mathrm{L}$ of the BLY buffer and $5.6 \mu \mathrm{g}$ of RNA Carrier were added to $200 \mu \mathrm{L}$ of each solution into a 2 $\mathrm{ml}$ tube. Both tubes were incubated at $56^{\circ} \mathrm{C}$ and for 20 minutes then $250 \mu \mathrm{L}$ of $97 \%$ ethanol was added, mixed by pulse-vortex, incubated at room temperature for 5 minutes and centrifuged at 10,000 rpm for 1 minute. Then, $500 \mu \mathrm{L}$ of $\mathrm{WB} 1$ was added before centrifuging the tubes at $12,000 \mathrm{rpm}$ for 1 minute, and the same process was repeated twice using $\mu \mathrm{L} 500$ of WB2. The tubes caps were left open to dry any residual ethanol at $56^{\circ} \mathrm{C}$ for 3 minutes. Viral nucleic acid was eventually eluted by adding $50 \mu \mathrm{L}$ of elution buffer and centrifuging the tubes at 16,000 $\mathrm{g}$ for 1 minute.

\section{Real-time PCR reactions}

For DNA amplification, $5 \mu \mathrm{L}$ of eluted viral nucleic acid was added to a total of $15 \mu \mathrm{L}$ of the master mix. The master mix was prepared by adding $10 \mu \mathrm{L}$ of the lyophilized OneStep $2 \mathrm{X}$ qPCR Master Mix, $1 \mu \mathrm{L}$ HBV primer/probe mix and $4 \mu \mathrm{L}$ RNase/DNase free water. The cycling conditions were started by activating the enzyme for 2 minutes at $95^{\circ} \mathrm{C}$, followed by 50 cycles of denaturation for 10 seconds at $95^{\circ} \mathrm{C}$ and then data collection for 60 seconds at $60^{\circ} \mathrm{C}$.

For RNA amplification, $5 \mu \mathrm{L}$ of eluted viral nucleic acid was added to a total of $15 \mu \mathrm{L}$ of the master mix. The master mix was prepared by adding $10 \mu \mathrm{L}$ of the lyophilized OneStep 2X RT-qPCR Master Mix, $1 \mu \mathrm{L} \mathrm{HCV}$ primer/probe mix and $4 \mu \mathrm{L}$ RNase/DNase free water. The cycling conditions were started by a reverse transcription step for 10 minutes at $55^{\circ} \mathrm{C}$, followed by activating the enzyme for 2 minutes at $95^{\circ} \mathrm{C}$, followed by 50 cycles of denaturation for 10 seconds at $95^{\circ} \mathrm{C}$ and then data collection for 60 seconds at $60^{\circ} \mathrm{C}$.

Real-time PCR reactions were carried out on the Applied Biosystems 7500 Fast Real-Time PCR System (Thermo Fisher Scientific, Massachusetts, United States) without activating the fast cycling option.

\section{Nucleic acid concentration}

Yield and purity of extracted viral nucleic acid were measured from $1 \mu \mathrm{L}$ of eluted samples, from each of the five kits, using the NanoDrop ND-1000 UV-Vis Spectrophotometer (Thermo Fisher Scientific, Massachusetts, United States).

\section{Results}

\section{Viral nucleic acid yield}

Eluted viral nucleic acid from each of the five different extraction kits was assessed by NanoDrop (Table 1). It is expected that the concentration of viral DNA or RNA in patient samples are hardly detectable by using spectrophotometry. Alternatively, viral loads are assessed using real-time PCR amplification to accurately determines the quantity of viral nucleic acid in biological samples. Spectrophotometric measurements of extracted DNA concentrations showed considerably variable quantities ranging from to 0.2 to $377.2 \mathrm{ng} / \mu \mathrm{L}$ with purity, as determined by assessing the $260 / 280$, ranging from 0.06 to 22.6 . Also, RNA concentrations showed even lower quantities ranging from to 0.06 to $1.86 \mathrm{ng} / \mu \mathrm{L}$ with purity, as determined by assessing the $260 / 230$, ranging from 0.01 to 1.86 . 


\section{PCR amplification of viral targets}

The extracted samples from each of the extraction kits were amplified using qPCR, for hepatitis B, and by qRT-PCR for hepatitis C. The amplification reactions for all three targets were carried out using similar materials and consumables to prevent inter-experimental variations. After the PCR amplification cycles are finished, the software of the ABI 7500 fast real-time instrument was able to choose an optimized threshold based on the amplification curves of all reactions for each viral target. The $\mathrm{Ct}$ value is then calculated for each extraction kit that have been used (Table 2). To try and compensate for threshold settings by other real-time PCR instrument (Figure 1), we introduced two additional threshold points: one that is lower than the default (or optimized) threshold and one that is higher than the default (or optimized) threshold. The three Ct values for each extraction kit were plotted as a single box, with the high and low Ct values serving as error bars (Figure 2).

Table 1. Viral nucleic acid concentration and purity as assessed by NanoDrop form each extractions kit as compared to the normal saline and serum controls

\begin{tabular}{|c|c|c|c|c|c|}
\hline & STD & Kit C & Kit B & Kit R & Kit G \\
\hline DNA concentration & 446.7 & 3.3 & 1.1 & 377.2 & 0.2 \\
\hline DNA purity: 260/280 & 2.08 & 0.86 & 1.16 & 3.30 & 0.22 \\
\hline RNA Concentration & 41.4 & 0.88 & 0.66 & 22.6 & 0.06 \\
\hline RNA purity: $260 / 230$ & 1.66 & 0.47 & 0.91 & 1.86 & 0.01 \\
\hline
\end{tabular}

Table 2. Ct values after the amplification of $\mathrm{HBV}$ and $\mathrm{HCV}$ targets using $\mathrm{qPCR}$

\begin{tabular}{|c|c|c|c|c|c|c|c|}
\hline & Ct threshold & STD & Kit R & Kit G & Kit B & Kit Q & Kit C \\
\hline \multirow{3}{*}{ HBV } & High: 174,195 & 22.520 & 27.157 & 32.462 & 32.625 & 27.638 & 30.944 \\
\hline & Auto: 80,111 & 20.784 & 25.606 & 29.969 & 31.008 & 25.791 & 29.472 \\
\hline & Low: 57,389 & 19.912 & 25.034 & 29.215 & 30.518 & 25.100 & 29.008 \\
\hline \multirow{3}{*}{$\mathrm{HCV}$} & High: 502,764 & 21.611 & 24.737 & 25.363 & 27.480 & 24.712 & 25.266 \\
\hline & Auto: 366,753 & 20.972 & 24.043 & 24.693 & 26.836 & 23.963 & 24.612 \\
\hline & Low: 186,508 & 19.778 & 22.763 & 23.426 & 25.525 & 22.634 & 23.323 \\
\hline
\end{tabular}
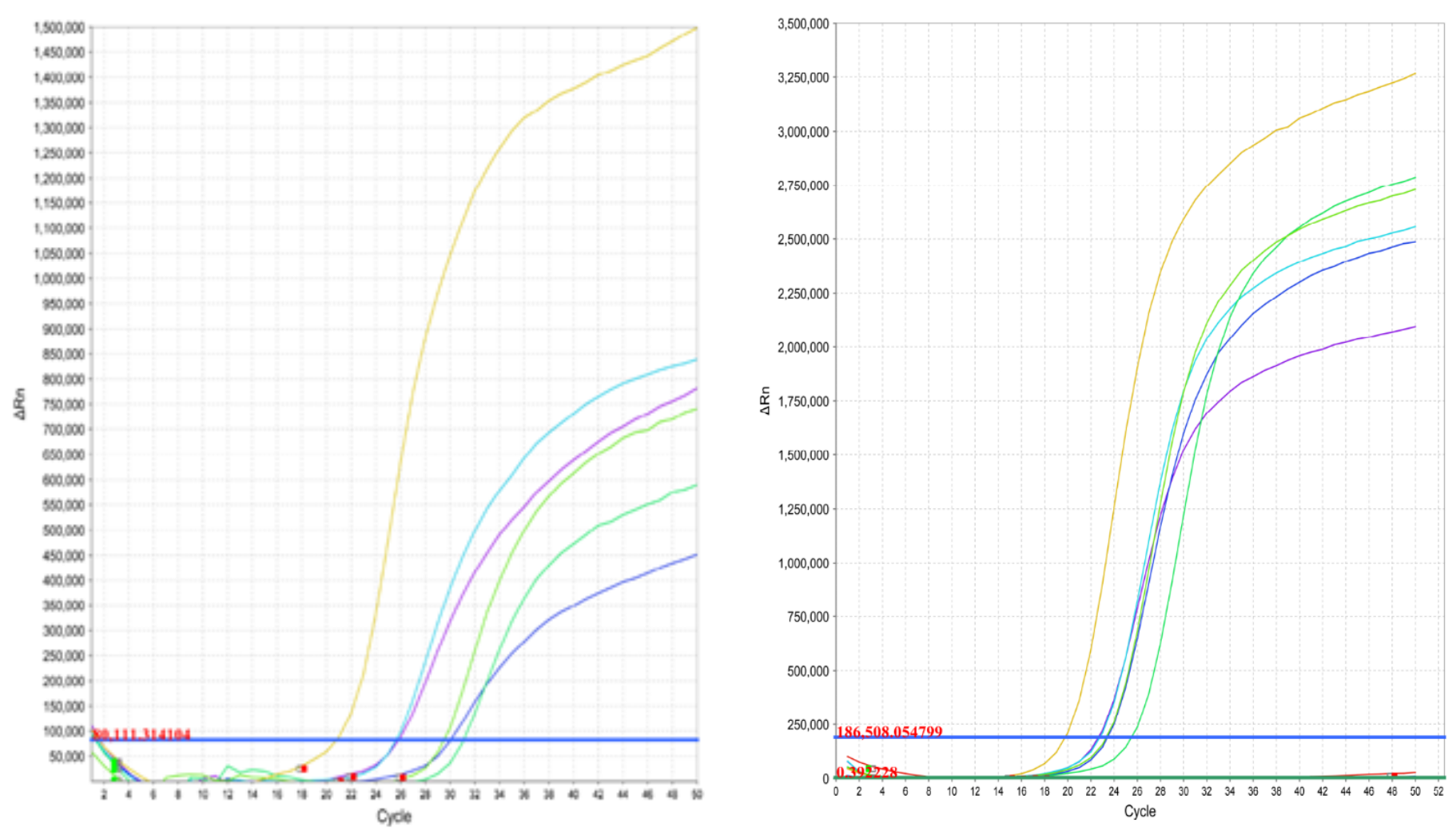

Figure 1. qPCR amplification curves form HBV DNA samples (left) and qRT-PCR amplification curves from HCV RNA samples (right) 
HBV

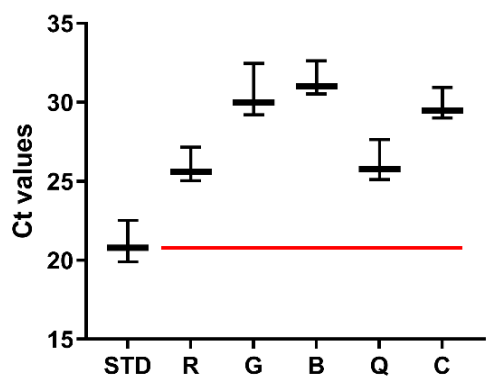

$\mathrm{HCV}$

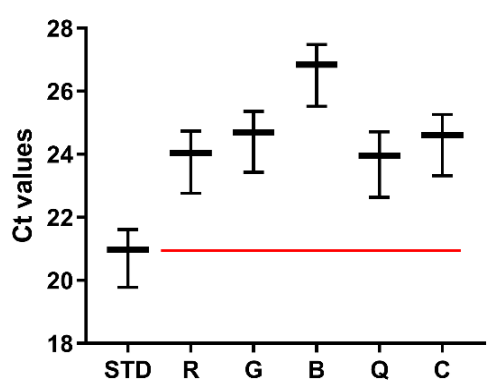

Figure 2. Ct values of the HBV PCR reaction (left) and HCV PCR reaction (right) from each of the viral nucleic acid extraction kits. STD: the standard control; R: RTA kit; G: Geneaid kit; B: Bioneer kit; Q: Qiagen kit; C: Canvax kit

\section{Discussion}

The effective quantification of viral nucleic acid in biological samples is of great medical and scientific value. Researchers and medical professionals use different approaches and methodologies to extract viral nucleic acid from cell free samples such serum, plasma, pleural effusions, gastric lavage, urine, etc. the extraction process does not come without a cost. The cost is in terms of viral nucleic acid integrity and purity. The sole purpose of many downstream diagnostic medical processes, after viral nucleic acid extractions, is the efficient quantification of target regions in the viral DNA or RNA using realtime PCR. The successful amplification of these target regions require that the template viral nucleic acid is intact and not fragmented, sheared or contaminated. Moreover, the extracted viral nucleic acid should be of sufficient quantities for the PCR instrument to successfully detect and amplify.

Here we compared the efficiency of five commercially available viral nucleic acid extraction kits. Each kit had its own, principles, methodology and protocol. Therefore, variations in the overall performance was expected. While their protocol was the most time consuming, we demonstrated that the $\mathrm{Q}$ kit was able to deliver abundant quantities of starting material for each of the viral nucleic acid enabling the successful amplification of both HBV and HCV targets. Moreover, possible variations in threshold settings did not affect the overall $\mathrm{Ct}$ value when compared to the Ct value of the standard control. Although the nucleic acid quantification, using the NanoDrop, did not provide acceptable evidence of the actual concentration of DNA and RNA in the eluted samples. Real-time PCR provided an adequate quantitative solution to measure the starting material present in the extracted material using each of the kits.

Moreover, the $\mathrm{R}$ kit was also successful in delivering adequate viral nucleic acid quantities after the extraction process. In addition, the amplification curves of both HBV and HCV targets started in similar ranges by the real-time PCR from the R kit when compared to the $\mathrm{Q}$ extraction kit. The Qiagen extraction kits are considered the gold-standard extraction methodology in the market. This suggests that more starting material was present in the PCR reaction from the $\mathrm{R}$ kit, and therefore, would imply the superiority of their extraction protocol and overall methodology of the R kit when compared to other commercially available viral nucleic acid extraction kits.

\section{Acknowledgements}

The author would like to express his gratitude for Ms Areej AlJohani (BndrGene Medical Lab, Madinah, Saudi Arabia) for helping with the extraction procedures.

\section{References}

1. Berger A, Braner J, Doerr HW, Weber B (1998) Quantification of viral load: clinical relevance for human immunodeficiency virus, hepatitis $B$ virus and hepatitis $C$ virus infection. Intervirology 41: 24-34. [Crossref]

2. Huang JT, Liu YJ, Wang J, Xu ZG, Yang Y, et al. (2015) Next generation digital PCR measurement of hepatitis B virus copy number in formalin-fixed paraffin-embedded hepatocellular carcinoma tissue. Clinical Chemistry 61: 290-296. [Crossref]

3. Klein D (2002) Quantification using real-time PCR technology: applications and limitations. Trends Mol Med 8: 257-260. [Crossref]

4. Kok T, Wati S, Bayly B, Devonshire-Gill D, Higgins G (2000) Comparison of six nucleic acid extraction methods for detection of viral DNA or RNA sequences in four different non-serum specimen types. J Clin Virol 16: 59-63. [Crossref]

5. Lole KS, Arankalle VA (2006) Quantitation of hepatitis B virus DNA by real-time PCR using internal amplification control and dual TaqMan MGB probes. J Virol Methods 135: 83-90. [Crossref]

6. MacKenzie DJ, McLean MA, Mukerji S, Green M (1997) Improved RNA extraction from woody plants for the detection of viral pathogens by reverse transcriptionpolymerase chain reaction. Plant Dis 81: 222-226. [Crossref]

7. Palmer S, Wiegand AP, Maldarelli F, Bazmi H, Mican JM, et al. (2003) New realtime reverse transcriptase-initiated PCR assay with single-copy sensitivity for human immunodeficiency virus type 1 RNA in plasma. $J$ Clin Microbiol 41: 4531-4536. [Crossref]

8. Seah C, Chow V, Chan Y, Doraisingham S (1995) A comparative, prospective study of serological, virus isolation and PCR amplification techniques for the laboratory diagnosis of dengue infection. Serodiagnosis and Immunotherapy in Infectious Disease 7: $55-58$.

9. Shaw KJ, Thain L, Docker PT, Dyer CE, Greenman J, et al. (2009) The use of carrier RNA to enhance DNA extraction from microfluidic-based silica monoliths. Anal Chim Acta 652: 231-233. [Crossref]

10. Tian H, Hühmer AF, Landers JP (2000) Evaluation of silica resins for direct and efficient extraction of DNA from complex biological matrices in a miniaturized format. Anal Biochem 283: 175-191. [Crossref]

11. Wang J, Ali Z, Wang N, Liang W, Liu H, et al. (2015) Simultaneous extraction of DNA and RNA from Escherichia coli BL 21 based on silica-coated magnetic nanoparticles. Science China Chemistry 58: 1774-1778.

12. Zuo X, Xia F, Xiao Y, Plaxco KW (2010) Sensitive and selective amplified fluorescence DNA detection based on exonuclease III-aided target recycling. J Am Chem Soc 132: 1816-1818. [Crossref]

Copyright: (C2019 Suliman BA. This is an open-access article distributed under the terms of the Creative Commons Attribution License, which permits unrestricted use, distribution, and reproduction in any medium, provided the original author and source are credited. 